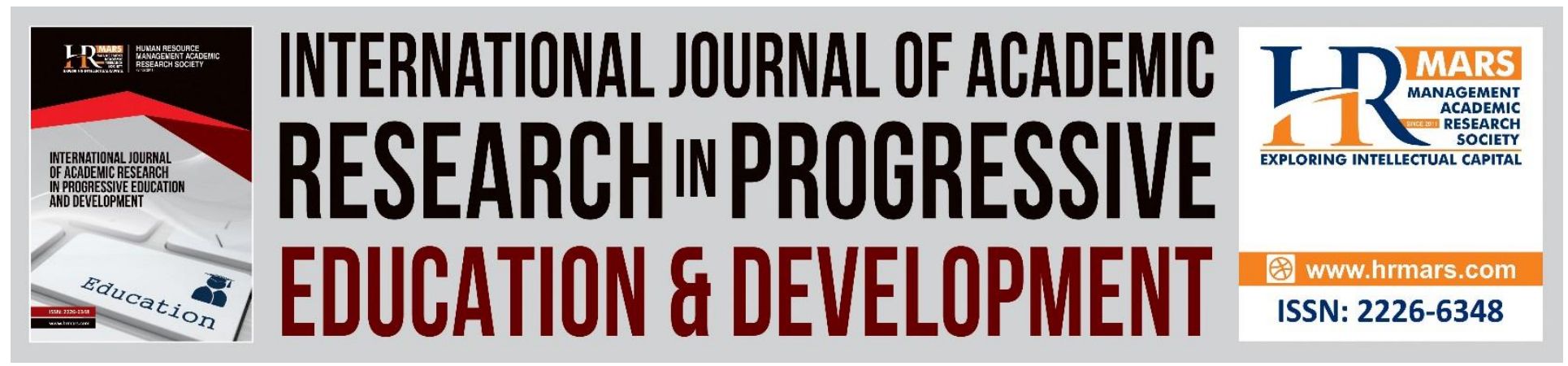

\title{
A Comparative Study of the Administrative Effectiveness of Principals of Public and Private Secondary School in Cross River State, Nigeria
}

\author{
Joseph Etiongbie Ogbiji
}

To Link this Article: http://dx.doi.org/10.6007/IJARPED/v7-i4/5335

DOI: $10.6007 /$ IJARPED/v7-i4/5335

Received: 11 Sept 2018, Revised: 23 October 2018, Accepted: 09 Nov 2018

Published Online: 13 Nov 2018

In-Text Citation: (Ogbiji, 2018)

To Cite this Article: Ogbiji, J. E. (2018). A Comparative Study of the Administrative Effectiveness of Principals of Public and Private Secondary School in Cross River State, Nigeria. International Journal of Academic Research in Progressive Education and Development, 7(4), 427-434.

Copyright: @ 2018 The Author(s)

Published by Human Resource Management Academic Research Society (www.hrmars.com)

This article is published under the Creative Commons Attribution (CC BY 4.0) license. Anyone may reproduce, distribute, translate and create derivative works of this article (for both commercial and non-commercial purposes), subject to full attribution to the original publication and authors. The full terms of this license may be seen

at: http://creativecommons.org/licences/by/4.0/legalcode

Vol. 7, No. 4, 2018, Pg. 427 - 434

http://hrmars.com/index.php/pages/detail/IJARPED

JOURNAL HOMEPAGE

Full Terms \& Conditions of access and use can be found at http://hrmars.com/index.php/pages/detail/publication-ethics 


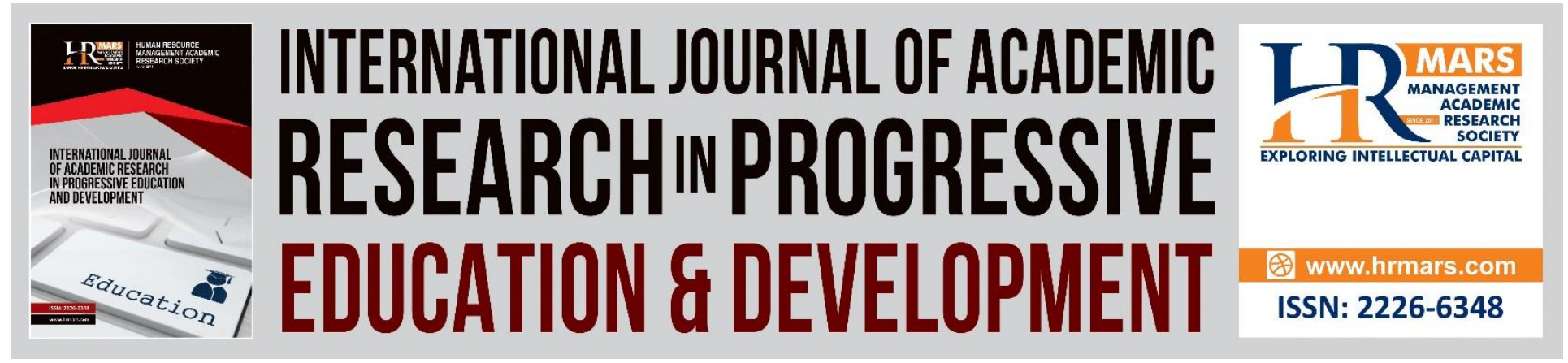

\title{
A Comparative Study of the Administrative Effectiveness of Principals of Public and Private Secondary School in Cross River State, Nigeria
}

\author{
Joseph Etiongbie Ogbiji, Ph.D \\ Department of Educational Foundations and Administration, Faculty of Education \\ Cross River University of Technology, Calabar, Calabar Campus
}

\begin{abstract}
This is a study on the comparative effectiveness between the administration of principals of public and private secondary schools in Cross River State. One null hypothesis was used to compare general administration, supervision, decision-making and motivational techniques between principals of the two groups of schools. A 20 item researcher-made questionnaire was used to collect data from 400 teachers that formed the respondents. Independent t-test was used to analyze the data collected. The result from the data analyzed showed that the four variables of effectiveness in general administration, supervision, decision-making and motivational techniques had calculated scores of $0.711,0.749,0.056$ and 0.598 respectively as against the calculated table value of 1.96. Thus the null hypothesis which stated that there was no significant differences in administrative effectiveness between public and private secondary schools in Cross River State was upheld. Hence the popular notion held by the public that private schools were administratively more effective becomes a myth except proved otherwise in future studies using other parameters not covered by this study. It was recommended that government should continue to organize conferences, workshops and retraining programmes for heads of public and private secondary schools in the state to update their knowledge and skills in administration.
\end{abstract}

\section{Introduction}

Nigeria after her political independence in (1960), has adopted education as an instrument for national development (FRN, 2013). This decision came as a realization that the knowledge, skills and attitudes necessary for building a modern society can only be developed through education. This realization came after a long period of neglect of Western Education by colonial government after it was introduced by Christian Missionary societies from 1843 (Fafunwa, 1995). Colonial administration only paid lips service to education as their objective was not the development of the country but the creation of markets, establishment of sources of raw 
DEVELOPMENT

Vol. 7, No. 4, 2018, E-ISSN: 2226-6348 ๑ 2018 HRMARS

materials for their industries at home and production of personnel to further the course of colonialism, trade and evangelization of the gospel. To this end the education provided emphasized literacy as against scientific knowledge, technical and vocational skills development which are critical for national development and individual self fulfillment.

Since the attainment of political independence, education has been in the concurrent legislative list of the three tiers of government that the country operates. (FRN, 1999). This has made the Federal, State and Local Government to be major stake holders in the formulation of educational policies as well as the provision of educational services. Realizing that the three tiers of government alone cannot provide adequate educational services for the teaming population of the country, government decided to liberalize the provision of educational services. This implies that voluntary organizations, communities and individuals have the right to establish schools, recruit teachers and pay their salaries as well as carryout the general administration of the schools in conformity with the laid down guidelines of government. Those schools that are set up by voluntary agencies, communities and individuals that are not directly administered by government are termed "private schools". This category of schools now exist at the primary, secondary and tertiary levels and are strong contenders today with government or "public schools" both in terms of population and administrative effectiveness (Adegun, 2005:196).

Although the public and private schools are guided by the same National Policy on Education, and pursue the same objective of providing standard and qualitative education, yet parenats and guardians appear to be more inclined to believe that principals of private schools are administrative more effective than those of public schools (Ogbiji and Ogbiji, 2014). This belief seems to have both theoretical and practical underpinnings. Public institutions and enterprises are seen as "no man's business" by both the workers and the public. More so, most public enterprises had been previously privatized due to poor performance and on account of advice by the World Bank and International Monetary Fund.

Personal observation has shown that since the privatization of such enterprises e.g. banks, farms and production companies, their annual reports have always shown steady progress. These indicators have fuelled the belief in the better administrative effectiveness of private institutions as compared to public ones. As far as schools are concerned, it has been observed that both public and private schools are regulated by government policy in terms of curriculum content, school calendar and daily school hours, staff qualification and teaching/learning facilities.

Commitment to bother teaching and learning appear to prevail in both schools at the same rate. Parents have however tended to believed in better performance of students of private schools in both internal and external examinations without consideration of other complimenting factors. For example most pupils in private schools are for well to do parent who provide adequate learning facilities for them both at school and at home. It sounds paradoxical to think that private schools are better organized and managed given the array of personnel and funding pumped into public schools as against the limitation of funding and personnel in private schools. This perception on the part of parents has brought about greater patronage of private schools by parents who can afford to pay high fees changed. The rate of withdrawal of pupils from public to private schools this days has been alarming. There is equally an alarming rate of proliferation of private schools at all levels of the education continuum (Ogbiji, 2005, 2014). As at 2018, Cross River State has over 500 private primary schools and over 380 private secondary schools (CRS 
SEB, 2018). Establishment of private educational institution is now seen as a lucrative business. This has raised the issue of whether private educational institutions should be taxed or aided by government (Denga, 2005).

Administrative effectiveness of any organization is determined by the extent to which organizational goals are achieved. Among the objectives of secondary education are the provision of education of a higher level, cater for differences in talents and future role performance through curriculum implementation, provision of trained man power at subprofessional level, inspiration for self improvement, national unity and to raise individual who can think for themselves, have respect for others, appreciate dignity of labour and respect for national values. (FRN/NPE, 2013: 27\&28). Principals of secondary schools as administrative heads are in the best position to use the human and material resources under their control to achieve set goals of the schools (Akilaiya, 2001). Ukeje (1992) Ogbiji (2011).

Principals could do this, according to Ajayi (2005), through instructional supervision, decision making style and motivational techniques. The power to motivate staff to use their creativity for the realization of institutional goals lies in the hands of the school head (Tess, 2003). Administrative effectiveness is equally determined by the degree of productivity, stability of the organization, entrenchment of justice and equity, turnover rate, degree of integration among members of the organization and society, maximization of individuals potentialities and value contributed to the society. Hence a school with low productivity, low morale, high turnover of staff, disgruntled and apathetic staff with little or no palpable contribution to society could be deemed to be ineffective. In this study we shall however use supervisory, motivational and decision making skills which Komolafe (2004) has identified as criteria for school administrators effectiveness to compare administrative effectiveness between public and private secondary schools in Cross River State of Nigeria.

\section{Purpose of the Study}

The main purpose of this research was to compare the administrative effectiveness of principals of public and private secondary schools in Cross River State using the opinion of teachers from the two category of schools. In specific terms the study used supervisory, motivational and decision-making techniques of the principals to determine the degree of their effectiveness.

\section{Research Hypothesis}

The null hypothesis tested for the study was:

1. There is no significant difference in administrative effectiveness between principals of public and private secondary schools in Cross River State.

\section{Research Area}

This research is carried out in Cross River State, one of the 36 states of Nigeria with a projected population of 4 million people. The state remains the only area in Nigeria with the largest rainforest belt famous for exotic flora and fauna which has attracted the World Wide Foundations for Nature to invest in the preservation of the forest and wildlife in the area.

Calabar, the state capital, is a famous tourist attraction that hosts Transcrop Hotels, Tinapa International Business Resort, the Calabar International Airport, the Sea Port, and calabar 
Vol. 7, No. 4, 2018, E-ISSN: 2226-6348 ๑ 2018 HRMARS

International Conference centre, among others. Educationally, there are the University of Calabar, Cross River University of Technology, the state College of Health Technology along with many famous public and private primary and secondary schools. As at 2013 , the state has a total of 1028 and 334 public primary and secondary schools respectively and 463 and 349 government approved private primary and secondary schools respectively (CRS, SEB, 2013). The research was carried out in Calabar and Ikom Education Zones which has a total of 245 and 154 public and private secondary school respectively.

\section{Research Method}

The survey research design was used in this study. Population of the study comprised of all teachers in public and private secondary schools in the two Education Zones of Calabar and Ikom. Multi-stage random sampling and proportional random sampling techniques were used in selecting samples for the study. The first stage was the selection of 8 out of the 13 Local Government Areas in the Zones. Simple random sampling technique was used to select 25 out of the existing 245 public secondary schools and 15 out of the 154 private secondary schools in the area. In all the total of 40 schools were sampled from where 400 teachers comprised the samples. The teachers were proportionately selected based on the population of teachers in each school.

The instrument used for data collection was a questionnaire tagged "Public/Private Secondary School Effectiveness Questionnaire" (PPSSEQ). The instrument was researcher made, designed to elicit information on the effectiveness of principals on general administrations, supervision, decision making and motivation of staff. It was designed on a 4point modified Likert scale of strongly agree, agree, disagree and strongly disagree, with the options carrying 4, 3, 2 and 1 point respectively. The instrument was validated by two experts in measurement and evaluation from the Faculty of Education of Cross River University of Technology, Calabar.

The instrument was administered by the researcher and two assistants who were thoroughly trained on what to do. Teachers from the two groups of school comprised the samples. Data was analyzed using t-test statistics for the only hypothesis used for the study. Result of the analysis was held at 0.05 level of significance. 
INTERNATIONAL JOURNAL OF ACADEMIC RESEARCH IN PROGRESSIVE EDUCATION AND

DEVELOPMENT

Vol. 7, No. 4, 2018, E-ISSN: $2226-6348$ @ 2018 HRMARS

\section{Result}

The Table below presents the data as analyzed.

Table 1: Comparative Effectiveness of administration of public and private secondary schools

\begin{tabular}{lllllll}
\hline Variable & $\begin{array}{l}\text { School } \\
\text { type }\end{array}$ & $\mathbf{N}$ & $\mathbf{X}$ & S.D. & df & t.cal \\
& Public & 262 & 53.244 & 6.5871 & & \\
\hline Main administration & Private & 108 & 53.824 & 7.343 & 368 & 0.711 \\
& Public & 262 & 21.2137 & 2.14905 & & \\
Supervision & Private & 108 & 21.44 & 2.81968 & 368 & 0.749 \\
& Public & 262 & 15.645 & 3.0704 & & \\
Decision making & Private & 108 & 15.667 & 3.5355 & 368 & 0.056 \\
Motivation & Public & 262 & 16.3396 & 2.6506 & & \\
& Private & 108 & 16.5794 & 3.78397 & 368 & 0.598 \\
Overall & Public & 262 & 26.6106 & 2.61428 & & \\
& Private & 108 & 26.8776 & 4.3705 & 368 & 0.528 \\
\hline
\end{tabular}

Critical t-value at 0.05 level of significance $=1.96$.

The table above shows the results of data analysis for the four variables tested. The calculated value for the main administration for both public and private school is 0.711 against the table value of 1.96. This shows that there is no significant difference in the administrative effectiveness between principals of public and private secondary schools in Calabar and Ikom Education Zones of Cross River State. The variables of supervision, decision-making and motivation had calculated values of $0.749,0.056$ and 0.598 respectively as against table value of 1.96. These show that there is no significant difference in supervision, decision making and motivation between public and private secondary schools in the two education zones in Cross River State. From the observation, all the four variables tested are less than the table value of 1.96. This implies that there is no significant difference in the administrative effectiveness between public and private secondary school principals in their general administration, supervision, decision making and motivational techniques.

\section{Discussion of Findings}

The findings of this study revealed that the only hypothesis used for the study was upheld. This means that there is no significant difference in the administrative effectiveness between principals of public and private secondary schools in Calabar and Ikom Education Zones of Cross River State. Principals effectiveness was compared using the variables of general administration, supervision, decision making and motivation. The findings show that administrative functions in both public and private secondary schools are the same. This finding goes to nullify the popular view that private school are administratively more effective than public ones (Ogbiji, 2014). The finding goes to show that there is no significant difference in principals internal supervision of their staff between the two groups of schools. Ajayi (2005) found out that more frequent teacher supervision by principals led, to greater teacher punctuality and commitment to curriculum 
Vol. 7, No. 4, 2018, E-ISSN: 2226-6348 @ 2018 HRMARS

implementation, which resulted in higher learning achievement. Edem (1987) also pointed out that better-informed and democratic supervision style results in the greater commitment and productivity of staff as against strict and autocratic supervisory style. The Federal Republic of Nigeria in the National Policy on Education (NPE, 2008) specifies the objectives for each level of education which the administration of both public and private schools pursue.

At the public secondary school level, government has vested supervisory functions on the Zonal Education Board, State Secondary Education Board and at the State Ministry of Education to ensure adequate supervision of primary and secondary schools in the state. More so each principal would like to carve a niche for himself and his school for productivity which is concomitant of effective administration. Principals of private schools as profit-oriented enterprises would equally want to earn a good name and reputation for effectiveness which will attract more patronage for their schools. From the stage set for the state and from the findings of this study, it appears that principals of both public and private schools are in a competition for effectiveness and efficiency. This race involves effectiveness in general administration, supervision, decision- making style and staff motivation which Komolafe (2004) identified as criteria for administrative effectiveness.

\section{Conclusion}

The findings of this study revealed that principals of both public and private secondary schools in Cross River State are effective in school administration. Principals in the schools of both divide do not significantly differ in their general administration, supervision, decisionmaking and staff motivation. The popular opinion held that private schools are better off does not apply in the variables investigated in this study. Principals of public and private secondary schools are equally effective in administration in the two education zones studied. This finding could be generalized for the entire state. More comparative studies need to be carried out in other states in Nigeria before it could be generalized for the entire country.

\section{Recommendations}

Based on the findings of this study, principals of public and private secondary schools should not relent in their administrative competitiveness. Government should on its part provide avenues through conferences and seminars for further training of school heads in both public and private sector to further enhance their administrative effectiveness. Equally, government and public school heads should team up to make public schools look physically more attractive than they presently are. Public schools should create more avenues for greater participation of parents in their activities and programmes to get them more informed of their achievement and challenges. 
INTERNATIONAL JOURNAL OF ACADEMIC RESEARCH IN PROGRESSIVE EDUCATION AND

DEVELOPMENT

Vol. 7, No. 4, 2018, E-ISSN: $2226-6348$ @ 2018 HRMARS

\section{References}

Adegun, O. A. (2005). Comparative study of the Administrative Effectiveness of Head Teacher in Public and Private Primary Schools in Ekiti State. Nigeria Journal of Educational Administration and Planning, 5(2), 196-200.

Ajayi, A. O. (2005). Improving Educational Access and Equal Educational Opportunities. A paper presented at Universal Basic Education (UBE) Board Conference for Head Teachers and Supervisors in Ekiti State.

Akilaiya, O. (2001). Educational Administration. Onitsha, Lincel Publishers.

CRS SEB (2018). Cross River State Secondary Education Board. Planning Research and Statistics Unit.

CRS/SEB (2013). Cross River State Secondary Education Board, Planning Research and Statistics Unit.

Denga, D. I. (2005). "Taxing or Aiding Private Educational Institutions in Nigeria: Problems and Prospects" in Nigeria Journal of Educational Administration and Planning, 5(2), 43-45.

Edem, D. A. (1987). Introduction to Educational Administration. Ibadan, Spectrum Books Ltd.

Fafunwa, A. B. (1995). History of Education in Nigeria. Ibadan, NPS Education publishers.

FRN (1999). Federal Republic of Nigeria Constitution, Lagos, Federal Ministry of Information.

FRN (2013). Federal Republic of Nigeria, National Policy on Education, Lagos, Federal Ministry of Information.

Komolafe, C. O. (2004). School Administration in Nigeria: Theory and Practice. Ado-Ekiti, Petoa Educational publishers.

Ogbiji, J. E. \& Ogbiji, S. A. (2014). A Boom in private secondary schools education in CRS, Nigeria: causes and consequences on Education system in Journal of Education and Social Research, (Italy) 4(6), 485-492.

Ogbiji, J. E. (2011). Educational Administration: An Introduction. Enugu, Master's press.

Ogbiji, J. E. (2018). "Implementation of Entrepreneurship Education programme in Tertiary Educational Institutions and Graduate Employment in Nigeria: the perspective of Cross River State. In International Journal of Human Resource Studies, 8(3), 254-262.

Ogbiji, J. E., Okey, S. \& Oshiomi, A. O. (2005). The role of private sector in providing Access 7 Equity to Primary/Secondary Education in Cross River State in NAEAP, in Nigeria Journal of Educational Administration and Planning, 5(2), 242.

Tess, S. M. (2003). Personnel Administration: Towards Optimum Productivity, Amemark Industries printers.

Ukeje, B. O., Akobogu, G. C. \& Ndu, A. (1992). Educational Administration. Enugu, Fourth Dimension Publishing Co. 